\title{
EFFECT OF COMPOST ON PROPERTIES AND SELECTIVITY COEFFICIENT OF SALT AFFECTED SOILS I. ON pH, EC AND SOLUBLE CATIONS AND ANIONS
}

\author{
S.A. Radwan, E.A. Abou Hussien and Basma M. Ahmed \\ Soil Science Dept. Fac. Agric. Menoufia Univ. ShebinElkom, Menoufia, Egypt.
}

Received: Sep. 4, 2019

Accepted: Oct. 21, 2019

\begin{abstract}
This study was carried out in Soil. Sci. Dept. Faculty of Agriculture, Menoufia University, Egypt during years of 2016 and 2017 on two salt affected soils of EIHamoul area, Kafr El-Sheikh Governorate, North Nile, Delta, Egypt. This was to study the effect of added compost with different rates and incubation period on the chemical properties of these soils. The applied compost rates were 0, 1, 2 and $3 \%$. The incubation periods were 0,3 and 6 months at the room temperature. The studied soil properties were $\mathrm{pH}, \mathrm{EC}$, the content of soluble cations $\left(\mathrm{Na}^{+}, \mathrm{Ca}^{2+}, \mathrm{Mg}^{2+}\right.$ and $\left.\mathrm{K}^{+}\right)$, soluble anions $(\mathrm{Cr}$, $\mathrm{CO}_{3}^{2-}, \mathrm{HCO}_{3}^{-}$and $\mathrm{SO}_{4}{ }^{2-}$ ).

The results indicated that, the increasing rates of added compost as well as incubation periods resulted in a decrease in soil $\mathrm{pH}$, soluble $\mathrm{Na}^{+}$and $\mathrm{Cr}$. Whereas, these led to an increase in EC. In general, compost application improved the chemical properties of the studied salt affected soil.
\end{abstract}

Key words: Salt affected soils, Compost, Incubation, Soil properties.

\section{INTRODUCTION}

Salt-affected soils are soils with high concentrations of dissolved mineral salts in their profiles. Such these dissolved salts adversely affect crop production (Rengasamy, 2006 and Wong et al., 2010). According to FAO (2016), Egypt's climate is characterized by a hot dry summer and mild winter, high evaporation rates between 1500 to $2400 \mathrm{~mm}$ per year and very low rainfall between 5 to $200 \mathrm{~mm}$ per year (Negm, 2017). The beneficial effects of composts on salt affected soil properties depend on soil texture and moisture conditions, as well as on the origin of organic matter. In saline soil, $\mathrm{Na}^{+}$constitutes a highly dispersive agent resulting directly in the breakup of aggregates.

The application of organic matter in salt affected soil promotes flocculation of clay minerals, which is an essential condition for the aggregation of soil particles and play an important role in control of erosion. It is well known that, the increase of salinity in soil limits its fertility. In fact, most salt-affected soils are deficient in nitrogen $(\mathrm{N})$, phosphorus $(P)$, and potassium (K).

The objective of the present study was to study the effect of compost as a soil conditioner and incubation periods on some chemical properties for two salt affected soils in Egypt.

\section{MATERIALS AND METHODS}

1. Materials

\section{a- Soil sampling}

Two salt affected soil samples were collected from two different locations of EL-Hamoul area Kafr El-Sheikh governorate, north Nile Delta, Egypt. These soils varied in their physical and chemical properties especially the content of total soluble salts (electrical conductivity) "EC" and exchangeable sodium percentage "ESP". The first soil $\begin{array}{llll}\text { was located at } & 31 & 18 & 12.6 \mathrm{~N} \text { and } 31\end{array}$ 03 28. $5 \mathrm{E}$ and cultivated with clover. 
The second one was located at 3118

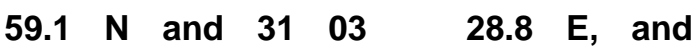
uncultivated but having grass like blink, shrew and throat. Irrigation water source having $E c_{w}$ value of $0.8 \mathrm{dS} / \mathrm{m}$ was from ElZawya canal Samples were collected from the surface $(0-20 \mathrm{~cm})$ of each soil, air - dried ground and sieved through a 2 $\mathrm{mm}$ sieve. Then the fine fraction $(<2 \mathrm{~mm})$ was analyzed for some physical and chemical properties according to
Cottenie et al. (1982). The obtained data are recorded in Table (1).

\section{b- Compost}

The used compost was produced from the mixture of maize stalks and farmyard manure at ratio of 65:35. Compost was, air dried ground and analyzed for some physical and chemical properties according to the methods described by Page et al. (1982). The obtained data is recorded in Table (2).

Table1: Main properties of the used two soils

\begin{tabular}{|c|c|c|}
\hline \multirow[t]{2}{*}{ Properties and units } & \multicolumn{2}{|c|}{ Soil number } \\
\hline & SAS1 & SAS2 \\
\hline \multicolumn{3}{|l|}{ Particles size distribution (\%) } \\
\hline Coarse sand & 8 & 4 \\
\hline Fine sand & 12 & 4 \\
\hline Silt & 40 & 12 \\
\hline Clay & 40 & 80 \\
\hline Texture grade & Clay loam & Clay \\
\hline pH $(1: 2.5)$ soil water suspension & 8.52 & 8.53 \\
\hline$E C\left(d_{S m}^{-1}\right)$ Soil paste extraction & 3.28 & 22.93 \\
\hline \multicolumn{3}{|c|}{ Soluble Cations (meq/l) Soil paste ext. } \\
\hline $\mathrm{Na}^{+}$ & 9.80 & 136.8 \\
\hline $\mathrm{K}^{+}$ & 0.68 & 6.52 \\
\hline $\mathrm{Ca}^{2+}$ & 6.48 & 40.9 \\
\hline $\mathrm{Mg}^{2+}$ & 8.50 & 45.8 \\
\hline \multicolumn{3}{|c|}{ Soluble anions (meq/l) Soil paste ext. } \\
\hline $\mathrm{Co}_{3}{ }^{2-}$ & 0 & 0 \\
\hline $\mathrm{HCO}_{3}^{-}$ & 8.63 & 31.85 \\
\hline $\mathrm{Cl}^{-}$ & 10.52 & 145.1 \\
\hline $\mathrm{SO}_{4}{ }^{2-}$ & 5.44 & 53.18 \\
\hline Organic matter "O.M" (\%) & 1.36 & 0.35 \\
\hline CEC (c.mole/kg) & 35.53 & 46.5 \\
\hline \multicolumn{3}{|c|}{ Exchangeable cations (c.mole/kg) } \\
\hline $\mathrm{Na}$ & 9.58 & 15.5 \\
\hline $\mathbf{K}$ & 3.26 & 2.95 \\
\hline $\mathrm{Ca}$ & 8.88 & 11.88 \\
\hline Mg & 11.63 & 13.40 \\
\hline ESP (\%) & 26.92 & 33.48 \\
\hline
\end{tabular}


S.A. Radwan, et al.,

Table (2): Some physical and chemical properties of the compost and its content of nutrients.

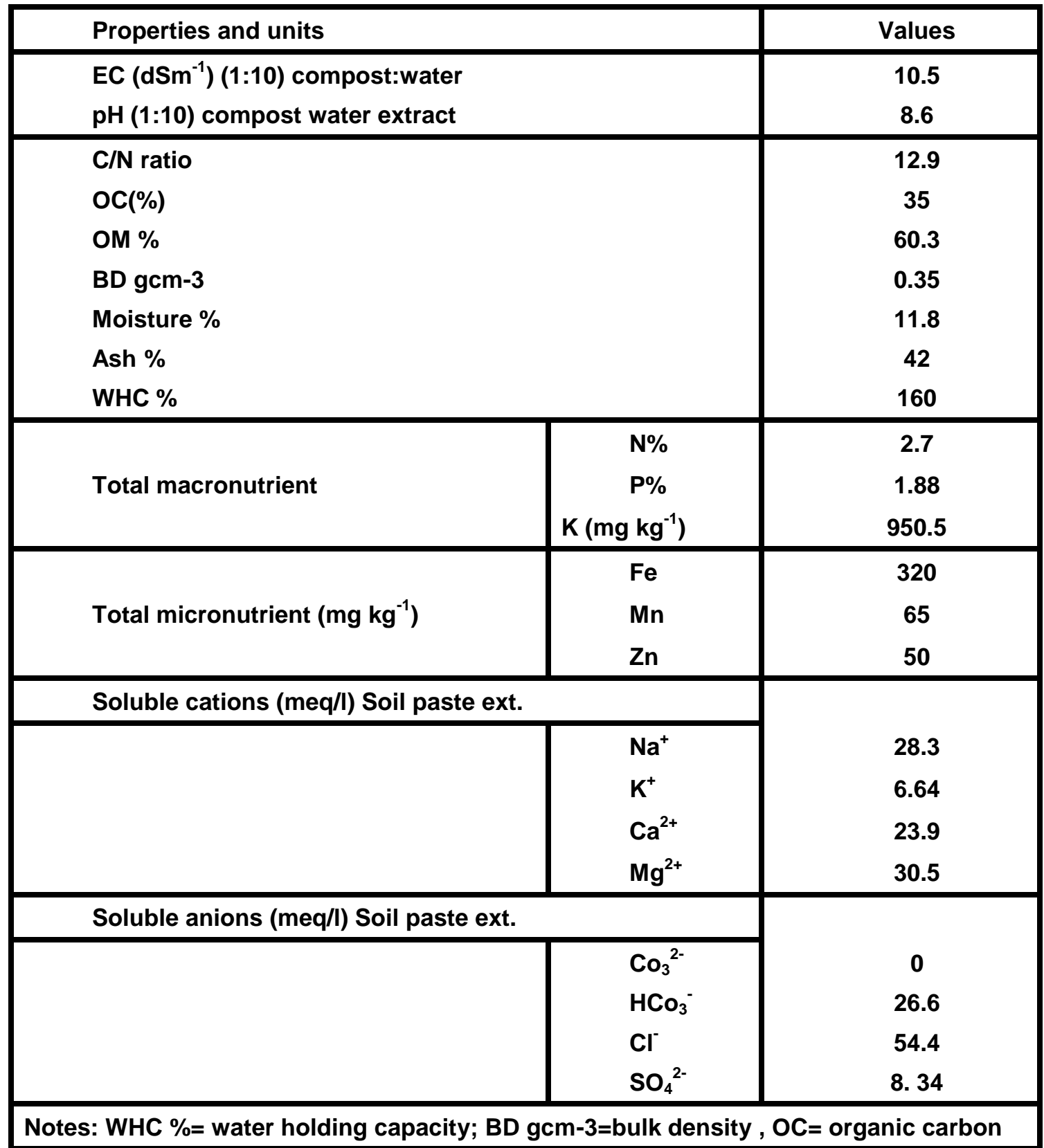

\section{Incubation Experiment}

A pot experiment was conducted at the green house of Soil Science Department, Faculty of Agriculture, Menoufia University Shibin El-Kom, Egypt during the two years of 2016 and 2017. In this experiment 72 plastic pots with $15 \mathrm{~cm}$ in both the depth and inter diameter were used. These pots were divided into two main groups each group (36 pots) was used for each of the two salt affected soils. Each pot was filled with one $\mathrm{Kg}$ of the soil sample. The pots of each main group were divided into four sub groups (9 pots/sub group) representing the application rates of compost. i.e. $0,1,2$ and $3 \%$. Added compost was mixed with the soil sample 
in each pot. The pots of each sub group divided into three sub groups (3pots/sub group) representing three incubation periods namely 0,3 and 6 months. The applied treatments for each soil were arranged in the experimental units in completely randomized block design with three replicates. All experimental units were incubated at room temperature $(25 \pm$ $\left.2{ }^{\circ} \mathrm{C}\right)$ for the three above mentioned incubation periods. All pots were moisted every three days by tap water at field capacity. At the end of each incubation time, the soil of the three replicates of each treatment was taken separately, air dried, ground, sieved through a $2 \mathrm{~mm}$ sieve and analyzed for their chemical properties. These properties were $\mathrm{pH}$, $E_{e}$ and soluble cations and anions.

\section{Statistical Analysis.}

The obtained data were statistically analyzed using 3 way completely randomized design with three replicates using the Costat statistical software (Costat 6.311, Copyright (C) 1998-2005).

\section{RESULTS AND DISCUSSION}

Effect of added compost rates and incubation periods on $\mathrm{pH}$ and EC of salt affected soils.

Data in Table (3) showed that, the average values of $\mathrm{pH}$ were decreased significantly in the two studied soils with increasing the compost rates. The mean $\mathrm{pH}$ values of the two soils were 8.64, $8.56,8.47$ and 8.42 at $0,1,2,3 \%$ compost rates respectively. Also, at the same compost rate, the increasing of incubation period resulted in a significant decrease of soil $\mathrm{pH}$. The mean $\mathrm{pH}$ values at 0,3 and 6 months incubation periods with the compost rates were 8.71, 8.53 and 8.33 respectively. In addition, the average values of EC were increased significantly in the studied soils with the increasing rate of added compost. The mean EC values of the two soils were 9.35, 9.97, 10.36 and $10.65 \mathrm{dSm}^{-1}$ at 0,1 ,
$2,3 \%$ compost rates respectively. Similar trend was observed with the increase in the incubation period, where the mean value of EC were 9.88, 10.07 and 10.30 $\mathrm{dSm}^{-1}$ at the 0,3 and 6 months incubation periods respectively.

Mekail, et al. (2000) found that, the pH values of soils treated with different rates of composted plant residues were decreased compared to the control. This decrease was significant before cultivation and after the two successive crops. There was also, a decreasing trend in $\mathrm{pH}$ value with land use time passing even in the control. In field experiments Wang and Yang (2003) and Rehan, et al. (2004) indicated that, the application of organic materials prevented soil $\mathrm{pH}$ from decreasing. They added that, increasing application rate of composted plant residues to sandy soil led to slight decrease in the soil $\mathrm{pH}$ as compared to either control or mineral fertilizers. One efficient way to increase SOM level is compost application, produced especially from biomass wastes. However, the essential influencing factors for SOM-enrichment are quantity, type and degree of humification of compost, the soil properties (soil type; clay content) and managements. Mature composts increase SOM much better than fresh and immature composts due to their higher level of stable C (Bouajila and Sanaa, 2011 and Daniel and Bruno, 2012). In addition, the high amount of $O M$ in compost increased $\mathrm{OC}$ in both soil and OC amount in uncultivated soil. This was higher than that in cultivated soil because of plant cultivation effect and increased the $O M$ degradation in cultivated soil (Soheil et al. 2012). In this respect, Mahmoud (2017) and Rabie (2019) found similar significant increase effect of incubation period on EC of different soils treated with different sources of organic materials. 
Effect of compost on properties and selectivity coefficient of salt affected soils...

Table (3): Effect of compost application and incubation period "P" (months) on ECdSm ${ }^{-1}$, $\mathrm{pH}$ values in two salt affected Soils.

\begin{tabular}{|c|c|c|c|c|c|c|c|c|c|}
\hline \multirow{2}{*}{$\begin{array}{l}\text { Salt } \\
\text { affected } \\
\text { soils }\end{array}$} & \multirow{2}{*}{$\begin{array}{c}\begin{array}{c}\text { Compost } \\
\text { application }\end{array} \\
\text { Compost rates\% }\end{array}$} & \multicolumn{4}{|c|}{ EC } & \multicolumn{4}{|c|}{$\mathrm{pH}$} \\
\hline & & PO & P3 & P6 & Mean & P0 & P3 & P6 & Mean \\
\hline \multirow{4}{*}{ SAS1 } & 0 & 2.86 & 2.83 & 2.80 & 2.83 & 8.68 & 8.56 & 8.44 & 8.56 \\
\hline & 1 & 2.90 & 3.04 & 3.26 & 3.07 & 8.62 & 8.46 & 8.39 & 8.49 \\
\hline & 2 & 3.08 & 3.14 & 3.46 & 3.23 & 8.52 & 8.41 & 8.30 & 8.41 \\
\hline & 3 & 3.19 & 3.23 & 3.61 & 3.34 & 8.47 & 8.39 & 8.26 & 8.37 \\
\hline \multicolumn{2}{|r|}{ Mean } & 3.01 & 3.06 & 3.28 & 3.12 & 8.57 & 8.46 & 8.35 & 8.46 \\
\hline \multirow{4}{*}{ SAS2 } & 0 & 21.07 & 21.21 & 21.03 & 21.10 & 8.88 & 8.76 & 8.56 & 8.73 \\
\hline & 1 & 21.99 & 22.65 & 23.00 & 22.55 & 8.79 & 8.65 & 8.44 & 8.63 \\
\hline & 2 & 22.95 & 23.33 & 23.75 & 23.34 & 8.69 & 8.56 & 8.33 & 8.53 \\
\hline & 3 & 23.09 & 23.68 & 23.94 & 23.57 & 8.65 & 8.48 & 8.27 & 8.47 \\
\hline \multicolumn{2}{|r|}{ Mean } & 22.28 & 22.72 & 22.93 & 22.64 & 8.75 & 8.61 & 8.40 & 8.59 \\
\hline G Means & & 9.88 & 10.07 & 10.30 & 23.03 & 8.71 & 8.53 & 8.33 & 8.52 \\
\hline \multicolumn{10}{|l|}{ LSD $_{0.05}$} \\
\hline Soils & & & & & 0.0269 & & & & 0.03 \\
\hline Compost & & & & & 0.0240 & & & & 0.02 \\
\hline Incubation & & & & & 0.0208 & & & & 0.02 \\
\hline
\end{tabular}

Effect of compost rates and incubation periods on the content of soluble cations of studied soils.

Date in Table (4) showed that, the average content of $\mathrm{Na}^{+}$were decreased significantly with increasing rate of added compost in the studied soils. The mean contents of $\mathrm{Na}^{+}$in these soils was $56.60,56.09,55.57$ and $55.06 \mathrm{meq} / \mathrm{l}$ at 0,1 ,
2 and $3 \%$ of compost rates with the different incubation periods respectively. Regarding to the influence of the incubation periods on the content of soluble $\mathrm{Na}^{+}$in the studied soils, data showed that the mean content of $\mathrm{Na}^{+}$ were $55.95,55.89$ and $55.65 \mathrm{meq} / \mathrm{l}$ respectively at the incubation periods of 0,3 and 6 months. Also, data in Table (4) 
S.A. Radwan, et al.,

showed that, the average content of $\mathrm{K}^{+}, \quad \mathrm{Ca}{ }^{2+}$ and $\mathrm{Mg}^{2+}$ were increased

\begin{tabular}{|c|c|c|c|c|c|c|c|c|c|c|c|c|c|c|c|}
\hline \multirow{4}{*}{ 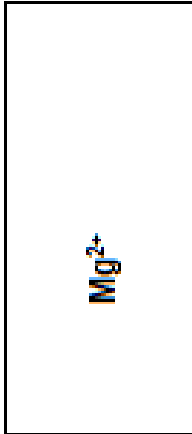 } & $\begin{array}{l}\overline{0} \\
\stackrel{0}{\Sigma}\end{array}$ & 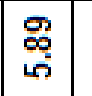 & ָุ & $\overbrace{\infty}^{m}$ & $\begin{array}{l}0 \\
\substack{0 \\
\infty \\
\infty}\end{array}$ & مُ & $\underset{\text { ป̇ }}{\text { J }}$ & 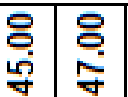 & \begin{tabular}{|l|} 
\\
\\
$\dot{g}$
\end{tabular} & 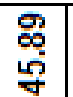 & $\begin{array}{l}0 \\
\stackrel{0}{0} \\
\stackrel{0}{0}\end{array}$ & & $\tilde{o}$ & z & $\frac{9}{6}$ \\
\hline & 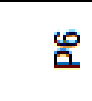 & \begin{tabular}{l|} 
\\
0 \\
0
\end{tabular} & ف् & 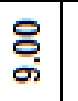 & 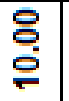 & $\underset{\infty}{\mp}$ & ֻู & 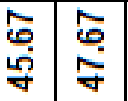 & $\begin{array}{l}8 \\
0 \\
0\end{array}$ & $\begin{array}{l}\mathcal{F} \\
\text { of }\end{array}$ & 竎 & & & & \\
\hline & $\dddot{2}$ & 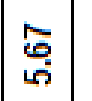 & 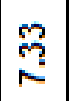 & $\overbrace{\infty}^{\infty}$ & $\widehat{\widehat{G}}$ & مִ & ঙ্ণে & 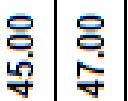 & \begin{tabular}{|c|} 
\\
g. \\
g.
\end{tabular} & $\begin{array}{l}0 \\
0 \\
\dot{g} \\
\dot{g}\end{array}$ & $\begin{array}{l}\text { స్ర } \\
\text { స్ }\end{array}$ & & & & \\
\hline & ㅇ & $\stackrel{0}{0}$ & 包 & 产 & ڤ్. & 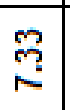 & 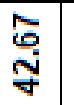 & 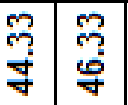 & 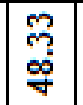 & $\begin{array}{l}7 \\
\text { s. }\end{array}$ & $\frac{O}{\dot{0}}$ & & & & \\
\hline \multirow{4}{*}{ త్ర } & 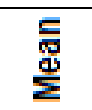 & $\underset{+}{Z}$ & | & חָ & 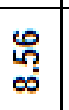 & $\begin{array}{l}\text { fy } \\
6\end{array}$ & 包 & 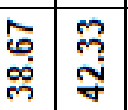 & $\begin{array}{l} \\
\\
\dot{6}\end{array}$ & $\begin{array}{l}\text { J. } \\
\text { ơ }\end{array}$ & : & & $\dddot{m}$ & ชี & בֶ. \\
\hline & $\mathscr{2}$ & m & ¿্. & 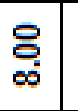 & ले & శ్ & 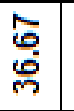 & \begin{tabular}{l|l} 
& 8 \\
& 0 \\
& $\dot{j}$ \\
\end{tabular} & \begin{tabular}{|c|}
$\hat{6}$ \\
$\tilde{y}$
\end{tabular} & 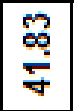 & 宅 & & & & \\
\hline & $\check{2}$ & $\stackrel{0}{+}$ & 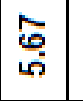 & $\stackrel{\Re}{\stackrel{2}{\sim}}$ & $\widehat{0}$ & 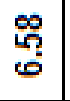 & 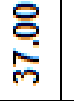 & 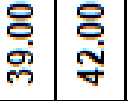 & $\begin{array}{l}\stackrel{8}{0} \\
\dot{\sigma}\end{array}$ & $\frac{8}{\dot{q}}$ & స్ స్ & & & & \\
\hline & ㅇ & ש্ & ది & 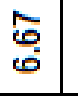 & @ִ & જ్ & 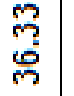 & 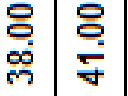 & 色 & హ్ & I̊ & & & & \\
\hline \multirow{4}{*}{$\dot{ \pm}$} & 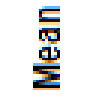 & 菅 & $\stackrel{\circ}{0}$ & $\underset{0}{\mathbb{N}}$ & $\underset{0}{\tilde{O}}$ & 包: & ஜ̊. & $\underset{0}{\mathbb{E}}$ & $\stackrel{\infty}{\Gamma}$ & గ్ర్య & 员 & & & : & $\stackrel{0}{\circ}$ \\
\hline & $\mathscr{2}$ & $\begin{array}{ll}0 \\
\stackrel{0}{0} \\
\stackrel{0}{0}\end{array}$ & $\mid$ & 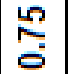 & $\begin{array}{c}2 \\
\stackrel{2}{0}\end{array}$ & : & 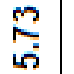 & \begin{tabular}{l|c}
$\stackrel{R}{2}$ \\
0 \\
0
\end{tabular} & 吕 & ஓ్రి & m్ & & & & \\
\hline & $\check{2}$ & 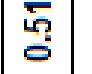 & $\mid$ & 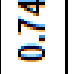 & 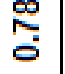 & 告: & 足 & 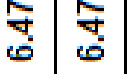 & 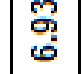 & స్త్ర & $\frac{F}{m}$ & & & & \\
\hline & 옹 & 莒 & $\stackrel{\overparen{o}}{\circ}$ & : & 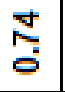 & $\begin{array}{l}\text { d़ } \\
\stackrel{0}{0}\end{array}$ & : & \begin{tabular}{l|l}
$\circ$ & 0 \\
& 0 \\
0
\end{tabular} & $\begin{array}{l}\stackrel{0}{0} \\
\vdots \\
\vdots\end{array}$ & స్రి & ஜू & & & & \\
\hline \multirow{4}{*}{ 要 } & 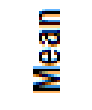 & $\begin{array}{l}\text { İ } \\
\stackrel{0}{0}\end{array}$ & $\begin{array}{l}\text { \% } \\
\text { \% }\end{array}$ & స్. & $\stackrel{\circ}{\circ}$ & $\begin{array}{l}R \\
\stackrel{0}{\circ}\end{array}$ & $\begin{array}{l}\vec{k} \\
\stackrel{5}{q}\end{array}$ & 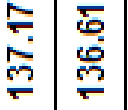 & 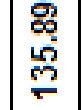 & 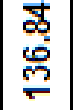 & $\underset{\sim}{ָ}$ & & & 옹 & Oั \\
\hline & $\mathscr{2}$ & $\begin{array}{l}\stackrel{9}{0} \\
\stackrel{0}{0}\end{array}$ & ळ. & స్ & \%̊. & 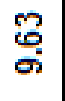 & ָ. & 官 & 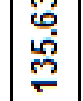 & 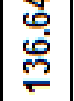 & 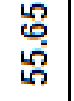 & & & & \\
\hline & $\check{2}$ & $\begin{array}{l}\stackrel{9}{0} \\
\stackrel{1}{0}\end{array}$ & ळু & ભ్ & ڤ్ & 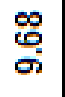 & 总 & 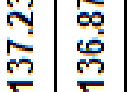 & 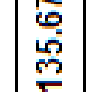 & \% & 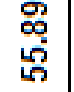 & & & & \\
\hline & ㅇ & 垫 & $\frac{ \pm}{\circ}$ & \%े & $\bar{\sigma}_{\sigma}$ & 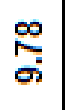 & 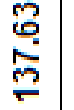 & 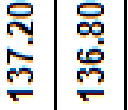 & 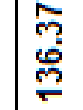 & 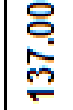 & 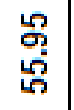 & & & & \\
\hline 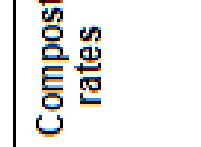 & 응 & 0 & - & $\sim$ & $m$ & & 0 & $-2 N$ & $m$ & $\overline{-1}$ & శ్ & & & & \\
\hline 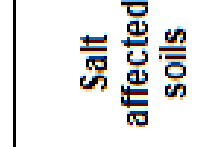 & & & nூ & & & & & 令 & & $\Sigma$ & 5 & 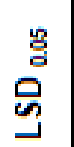 & & & $\begin{array}{l}\text { 음 } \\
\text { 思 } \\
\text { 晋 }\end{array}$ \\
\hline
\end{tabular}


significantly with increasing compost rates. The mean contents of $\mathrm{K}^{+}$were $16.06,19.78,26.73$ and $19.63 \mathrm{meq} / \mathrm{l}, \mathrm{Ca}^{2+}$ were 20.88, 25.39, 34.22 and $32.76 \mathrm{meq} / \mathrm{l}$ and $\mathrm{Mg}^{2+}$ were $19.52,22.88,31.98$ and $32.76 \mathrm{meq} / \mathrm{l}$ at $0,1,2$ and $3 \%$ compost respectively. Similar increases of soluble $\mathrm{K}^{+}, \mathrm{Ca}^{2+}$ and $\mathrm{Mg}^{2+}$ were observed with increasing incubation periods from 0,3 to 6 months. The mean content of $\mathrm{K}^{+}$ were 17.04, 17.89 and $20.49 \mathrm{meq} / \mathrm{l}, \mathrm{Ca}^{2+}$ were 23.56, 24.49 and $27.81 \mathrm{meq} / \mathrm{l}$ and $\mathrm{Mg}^{2+}$ were 23.8, 24.59 and $26.86 \mathrm{meq} / \mathrm{l}$ at incubation period 0,3 and 6 months, respectively. Soils having high concentrations of dissolved mineral salts could be had adversely affect on crop production (Rengasamy, 2006 and Wong et al., 2010). These salts are primarily composed of carbonates, chlorides, sulfates, and bicarbonates of calcium $\left(\mathrm{Ca}^{2+}\right)$, magnesium $\left(\mathrm{Mg}^{2+}\right)$, and sodium $\left(\mathrm{Na}^{+}\right.$) (Qadir et al., 2000 and Manchanda and Garg, 2008). The increase soluble $\mathrm{K}^{+}$, $\mathrm{Ca}{ }^{2+}$ and $\mathrm{Mg}^{2+}$ with the compost application could be attributed to the increase of chelating ability (i.e. the ability to form several bonds with a metal ion) of $\mathrm{Ca}^{2+}$ and $\mathrm{Mg}^{2+}$ in the soil. This enables them to replace $\mathrm{Na}^{+}$from the cation exchange complex. Also this could be decreasing the soil's ability to absorb $\mathrm{Na}^{+}$by reducing the sodium absorption rate (Lakhdar et al. 2009). The content of $\mathrm{Na}^{+}$in the soil is therefore reduced because it allows $\mathrm{Na}^{+}$to be disbursed and leached. The increasing of $\mathrm{H}+$ ions in soil solution resulting from the decomposition of compost, led to the increase in leaching and changing of soluble $\mathrm{K}^{+}, \mathrm{Ca}^{2+}, \mathrm{Mg}^{2+}$ contents in the studied soils. These findings are generally agreement with the findings of Gell et al. (2011).
Effect of compost rates and incubation periods on soluble anions of the studied soils.

Data in Table (5) show that, the addition of compost at different rates to the studied soils led to decrease in the content of soluble $\mathrm{Cl}^{-}$at the different incubation periods. The mean $\mathrm{Cl}^{-}$content were $60.11,59.47,58.77$ and 60.49 at 0,1 , 2 and $3 \%$ compost rates respectively. In addition, the compost application increased the average contents of $\mathrm{HCO}_{3}{ }^{-}$ and $\mathrm{SO}_{4}{ }^{2-}$ in the two studied soils. The mean contents of $\mathrm{HCO}_{3}^{-}$were 18.27, $19.85,20.86$ and $21.73 \mathrm{meq} / \mathrm{l}$ and for $\mathrm{SO}_{4}{ }^{2-}$ were 24.85, 28.29, 31.43 and $35.30 \mathrm{meq} / \mathrm{l}$ at $0,1,2$ and $3 \%$ compost respectively. At incubation periods of 0,3 and 6 months the mean contents of $\mathrm{Cl}^{-}$were 58.86, 61.48 and $58.78 \mathrm{meq} / \mathrm{l}$. At these periods $\mathrm{HCO}_{3}^{-}$were 19.55, 19.95 and $21.03 \mathrm{meq} / \mathrm{l}$ and $\mathrm{SO}_{4}{ }^{2-}$ were $29.10,29.87$ and $30.93 \mathrm{meq} / \mathrm{l}$ respectively. Compost could be considered as a critical source for the nutrients such as the soluble salts. Good quality compost has limited amounts of $\mathrm{Cl}^{-}$. Therefore, it should not cause phytotoxic effects after long term application. Compost can also have a significant concentration of sulfate, which can either be readily absorbed by the plant, or transformed by enzymatic activity to readily available forms. The increase of $\mathrm{Ca}^{2+}$ and $\mathrm{Mg}^{2+}$ in the soil, could be enabled them to replace $\mathrm{Na}^{+}$ from the cation exchange complex. This could be decreased the soil's ability to absorb $\mathrm{Na}^{+}$by reducing the sodium absorption rate. The $\mathrm{Na}^{+}$concentration in the soil is therefore reduced because it allows $\mathrm{Na}^{+}$to be disbursed and leached (Reddy and Crohn, 2012, Gransee and Führs, 2013 and Guangming et al., 2017). 


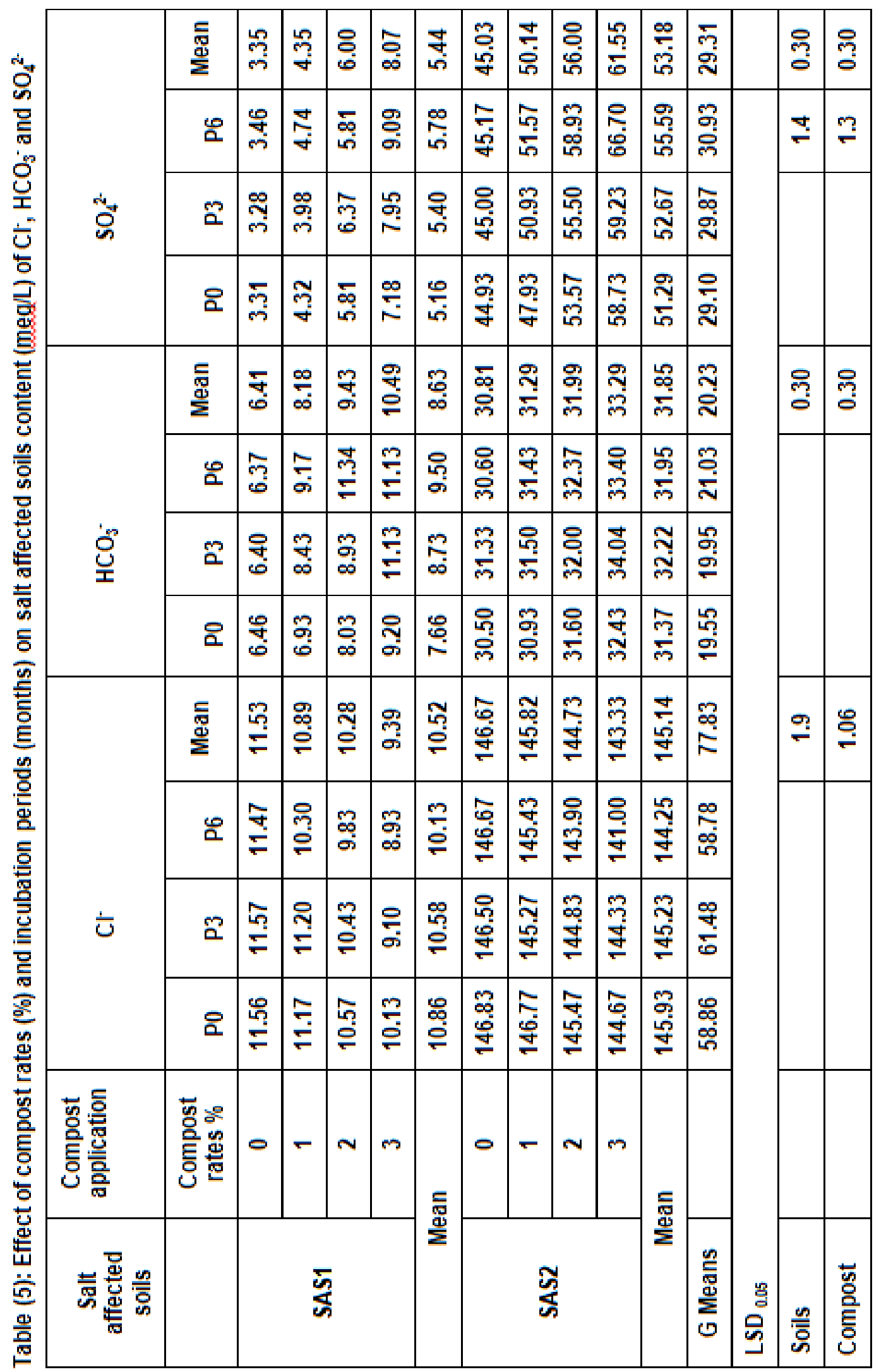




\section{CONCLUSION}

This study was conducted on samples collected from two soils of El-Hamoul area, Kafr El-Sheikh governorate, north Nile, Delta, Egypt. These soils are salt affected soils. From the obtained results, it can be concluded that, the addition of organic amendments such as compost could be the best solution for the problems of these soils. These amendments could be improve the chemical properties of these soils such as decrease of their $\mathrm{pH}$. In this study, the best rate of compost application was 3\% and the best incubation period was 6 months. Therefore compost application must be added to soil before cultivation by sufficient times.

\section{REFERENCES}

Bouajila, K. and M. Sanaa (2011). Effects of organic amendments on soil physico-chemical and biological properties. J. Mater. Environ. Sci. 2 : 485-490.

Costat 6.311, Copyright (C) (1988-2005). Cohort software 798 Lighthouse Are, PMB 320, Monterey, CA, 93940, USA Email: info@ Cohort. Com. http://www.cohort.com.

Cottenie, A., M. Verloo, L. Kickens, G. Velghe and R. Camerlynck (1982). Chemical Analysis of Plants and Soils. Laboratory of Analytical and Agrochemistry. State University, Ghent Belgium, pp: 63

Daniel, F. and G. Bruno (2012). Synergisms between Compost and Biochar for Sustainable Soil Amelioration, Management of Organic Waste, Dr. Sunil Kumar (Ed.), ISBN: 978-953-307-925-7. [Online] Available: http://www.intechopen.com(Sep. 2013)

FAO (2016). Regional Report "Egypt", 24p. Cited in http://www.fao.org/nr/water/aquastat/c ountries regions/EGY.
Gell, K., J.V. Groenigen and M.L. Cayuela (2011). Residues of bioenergy production chains as soil amendments: Immediate and temporal phytotoxicity. Journal of Hazardous Materials. 186 (2-3): 2017-2025.

Guangming, L., Z. Xuechen, W. Xiuping, S. Hongbo, $Y$. Jingsong and $W$. Xiangping (2017). Soil enzymes as indicators of saline soil fertility under various soil amendments. Agriculture, Ecosystems and Environment, 237: 274-279.

Lakhdar, A., M. Rabhi, T. Ghnaya, F. Montemurro, N. Jedidi and C. Abdelly (2009). Effectiveness of compost use in salt-affected soil. J Hazard Mater 171: 29-37 and 181:29-38.

Mahmoud, H.M.A. (2017). Organic amendments and their effect on status of some nutrients in soil and plant. Ph. D. Thesis, Fac. of Agric., Menoufia Univ., Egypt.

Manchanda, G. and N. Garg (2008). Salinity and its effects on the functional biology of legumes. Acta Physiol Plant 30: 595-618

Mekail, M.M., M.A. Morsy, S.M. Abdel-Aziz and M.B. Taha (2000). The effect of some composed plant residues on improving the productivity of sandy soil. B: Comparison between the direct and residual effect on some properties of soil for two successive crops. Minia. J. Agric. Res. \& Dev., 20 (2): 393-408.

Negm, A.M. (2017). The Nile Delta Part 3: Management of Salt-Affected Soil in the Nile Delta (Ed. Mohamed, N.N.), The Handbook of Environmental Chemistry, 55, Springer, 537p.

Page, A. L., R. H. Miller and D. R. Keeney (1982). Methods of Soil Analysis, Part 2. Chemical and Microbiological properties second Edition.Wisconsin, U.S.A.

Qadir, M., S. Schubert, A. Ghafoor and G. Murtaza (2000). Amelioration 
strategies for saline soils : a review. Land Degrad Dev 11: 501-521.

Rabie, S.T.M. (2019). Evaluation the agriculture environment quality in the contaminated and manured soils in North Africa. M. Sc. Thesis, Fac. of Agric., Cairo Univ., Egypt.

Reddy, N. and D. M. Crohn (2012). Compost induced soil salinity: a new prediction method and its effect on plant growth. Compost Science and Utilization, 20(3): 133-140

Rehan, M.G., A.H. El-Sayed, M.M. Hassan and M.A. Negm (2004). Direct and residual effect of mixing the added compost to calcareous soil with sulphur and phosphorus. I On crop yields and some soil properties. J. Agric. Sci. Mansoura Univ., 29(3): 1603 - 1614.
Rengasamy, P. (2006). World salinization with emphasis on Australia. J Exp Bot 58:1018-1023.

Soheil, R., M H. Hossien, S. Gholamreza, H. Leila, J. Mozhdeh and E. Hassan (2012). Effects of Composted municipal waste and its Leachate on Some Soil Chemical Properties and Corn Plant Responses. Int. Journal of Agriculture: Research and Review. 2 (6): 801-814.

Wang, M.C. and C.H. Yang (2003). Type of fertilizer applied to a paddy-upland rotation affect selected soil quality attributes. Geoder., 114 (1-2) : 93-108.

Wong, V.N.L., R.S.B. Green and B.W. Murphy (2010). Soil carbon dynamics in saline and sodic soils : a review. Soil use manage 26:2-11 
تأثير الكومبست علي الخواص و معامل الأفضلية فى الأراضي المتأثرة بالأملاح .

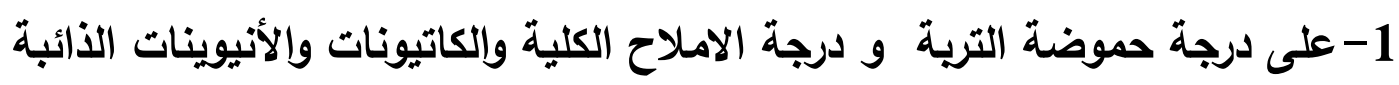

صلاح عبد المجيذ رضوان، الحسينى عبد الغفار أبوحسين، بسمة محى الاين أحمد

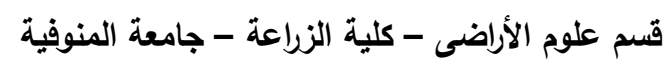

الملخص العربي أجريت هذه الدراسة بصوية ومعامل قسم علوم الأراضي - كلية الزراعة - جامعة المنوفية - مصر خلال عامي

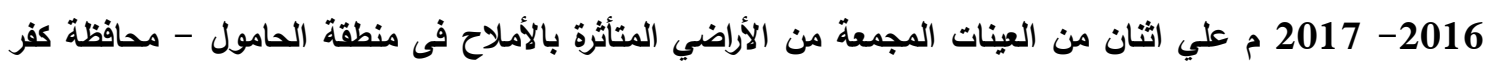

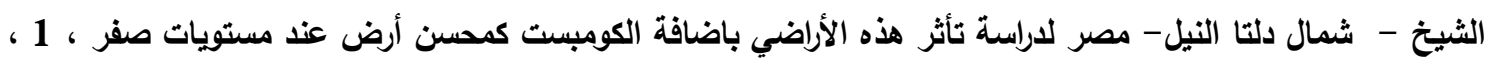

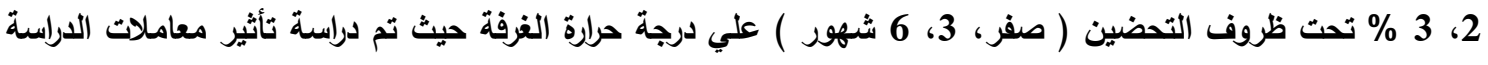

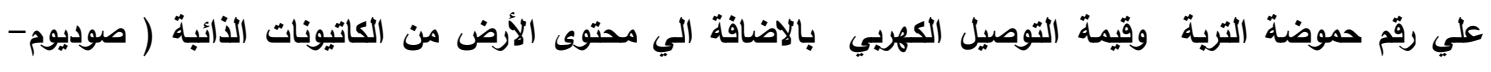

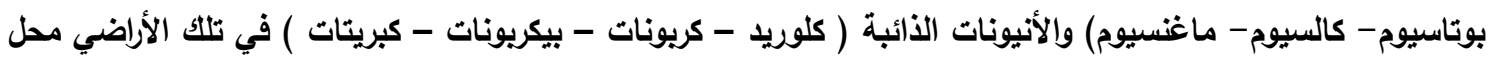
الدراسة وتقييم علاقتها بعوامل الداسية.

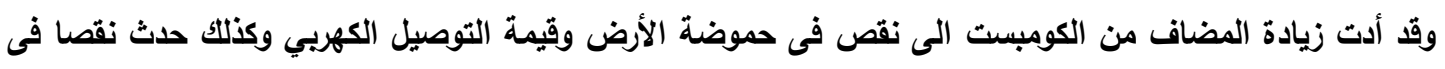

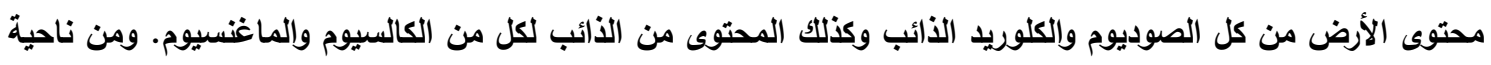

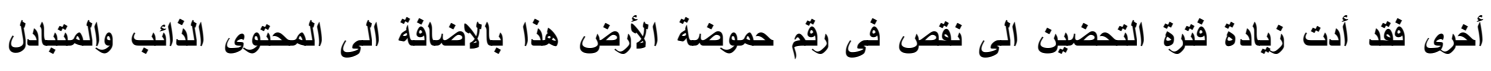

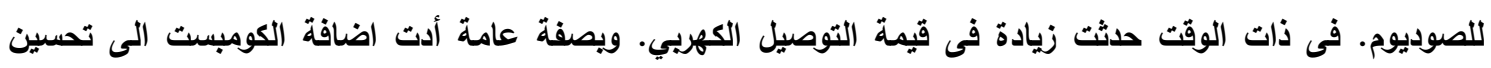

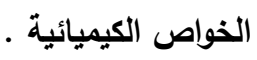

أسماء السيادة المحكمين أ.د/ نبيل سبع الرجال عبدالحميد زنق مركز البحوث الزراعية - الجيزة

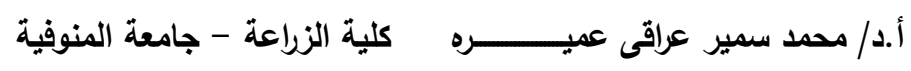


S.A. Radwan, et al., 